\title{
Diabetes Self-management Education Effect on Family Knowledge of Hypoglycemia Episodes Detection on Type 2 Diabetes Mellitus
}

\author{
Netha Damayantie*(D), Mursidah Dewi, Rusmimpong Rusmimpong, Cek Masnah \\ Department of Nursing, Politeknik Kesehatan Kementerian Kesehatan, Jambi, Indonesia
}

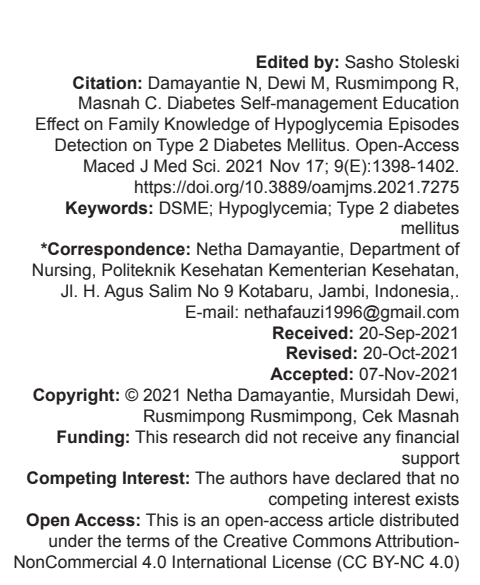

Introduction

Diabetes mellitus (DM), especially type 2, is a global health problem around the world. The International Diabetes Federation estimated an escalation of diabetes prevalence from 424.9 million in 2017 to about 628.6 million by 2045 [1]. More than 10.3 million people were living with DM in Indonesia [2]. About $90 \%$ of diabetes cases is type 2 DM (T2DM) with characteristics of insulin sensitivity disorders and/ or impaired insulin secretion [3]. Prevalence of DM in Indonesia based on doctor's diagnosis in the population aged $\geq 15$ years has increased from $1.5 \%$ in 2013 to $2.0 \%$ in 2018 [4], [5].

Administration of insulin therapy causes the main side effect of hypoglycemia. Other side effects include immunological reactions to insulin that can lead to insulin allergies or insulin resistance [3]. Hypoglycemia is a condition in which glucose levels in the blood decrease below the value of $70 \mathrm{mg} / \mathrm{dl}$ or less [6], [7]. Prevalence of hypoglycemia in T2DM patients can reach $70-80 \%$, which has a serious impact on morbidity, mortality, and quality of life [8]. Severe occurrence of hypoglycemia in T2DM patients reaches 3-73 episodes per 100 patients a year [6].
A common phenomenon in the clinical setting is that many patients argue that mild hypoglycemia as a consequence of hypoglycemia management to lower blood glucose levels, but actually mild hypoglycemia should not be ignored because it has the opportunity to become a more severe to lower blood glucose levels, but actually mild hypoglycemia should not be ignored because it has the opportunity to become a more severe hypoglycemia [9]. In addition, many patients are misunderstood in interpreting symptoms of hypoglycemia as a symptom of ketoacidosis, as a result of insulin administration that should be reduced or delayed [10]. Patients attempted to lower blood sugar levels without knowing the effects of using the drug where patients may experience severe hypoglycemia as the result. One of the reasons for the lack of patient knowledge about hypoglycemia is the lack of information provided by health workers [11].

Some models have been conducted to increase the knowledge and awareness about hypoglycemia in diabetic patients [12]. One of them was the integrated development model which can improve obedience significantly toward the treatment of DM patients $(p=0.00001)$ [13].

Self-instructional training model also used and can decrease the blood sugar level of DM Type II 
patients $(p=0.000)$ [14]. Another health education for diabetic patients used in Indonesia was based on the Health Belief Model using diet DM-Disk Management model that significantly increased knowledge $(p=0.020)[15]$.

As a long-term disease, patients with DM require lifetime care and management. However, $50-80 \%$ of diabetic patients did not have good ability and knowledge to self-care out their disease [16]. Therefore, diabetes self-management education (DSME) plays an important role in clinical management to reduce diabetes-related complications and premature deaths of diabetes [17].

DSME is a health education process for individuals or families in managing diabetes. DSME applies guidelines, counseling, and behavioral interventions to improve knowledge of diabetes and the skills of individuals and families in managing DM. The knowledge that can be helpful for patients with T2DM is called DSME [18].

DSME is a health education method which encourages participation and cooperation of DM patients. However, DSME with family target is to find out their ability in preventing hypoglycemia on patient that is mostly not developed by the community structure. Whereas family role is crucial in keeping the health status of DM patients. Family members can provide practical help, for example, they can help with blood glucose tests or by identifying signs of hypoglycemia.

The previous study showed that DSME can improve diabetic knowledge, diabetic self-care, and life quality [16], [19], [20], but no studies specifically focus on awareness and knowledge of the family members of type 2 diabetes patients on hypoglycemic detection.

This study aimed to evaluate DSME effect on family knowledge of hypoglycemia episodes detection on T2DM.

\section{Methods}

This was a quasi-experimental study with pre- and post-test with control group design. Subjects 62 patients with type 2 diabetes mellitus. They were divided into the intervention group $(n=31)$ and control group $(n=31)$. This study was conducted on the working area of Public Health Center Putri Ayu: Murni, Legok, Solok Sipin, and Sungai Putri, Jambi Province, Indonesia. Puskesmas Putri Ayu has the highest number of DM patients compared to Puskesmas in Jambi city.

This study was conducted from September to November 2019. The intervention group received DSME of diabetes mellitus with the socialization and competency phase for 2 weeks, competency enhancement for a week, implementation for 3 weeks, monitoring for a week, and evaluation for a week. For the control group at the time of filling out a questionnaire to measure knowledge, they were given leaflets on DM and hypoglycemia.

This research was carried out after obtaining description of ethical exemption by health research Ethics Committee Politeknik Kesehatan Kementerian Kesehatan Jambi with Number: LB.02.06/2/12/2019 [21].

The data collection instrument uses a questionnaire adopted from an existing questionnaire and has tested validity and reliability, to measure the family's ability to detect episodes of hypoglycemia. DSME applies guidelines, counseling, and behavioral interventions to improve knowledge of diabetes and the skills of individuals and families in managing DM [17]. The stages of activity:

a. Socialization and competency improvement, implemented to provide understanding and brainstorming with the family regarding the assistance of DSME with the stages of its activities.

b. Implementation. Activities in the form of mentoring the family in conducting self-care by providing health education about DM, identification of hypoglycemia risk factors, signs and symptoms of hypoglycemia, identification of glycemic status, and early management of hypoglycemia. The writer taught family about foot gymnastics, so they can teach it and accompany diabetic patients to do it at home.

c. Monitoring. The authors monitored with the team by making home visits in the intervention group. Reviewing the understanding of signs, symptoms, and early treatment in the event of hypoglycemia. The author provides reinforcement to increase family motivation

d. Evaluation. The authors measured the family's ability to detect episodes of hypoglycemia in diabetic patients after a post test.

During the activity, the authors assisted two researchers, before the analysis of the effectiveness of family-based DSME, data normality test was conducted using Shapiro-Wilk. Hypothesis testing used dependent t-test (paired t-test).

\section{Results}

The characteristic of respondents age and long suffering of T2DM shown in Table 1 . The characteristic of respondents gender, education, occupation, and glucometer ownership shown in Table 2.

The results showed that the average age of respondents in this study was 38.48 years, long 
Table 1: Respondents' characteristics based on age and long suffering of Type 2 diabetes mellitus

\begin{tabular}{|c|c|c|c|c|c|c|}
\hline \multirow[t]{2}{*}{ Characteristics } & \multicolumn{2}{|l|}{ Intervention } & \multicolumn{2}{|l|}{ Control } & \multicolumn{2}{|l|}{ Total } \\
\hline & Mean-median & Min-max & Mean-median & Min-max & Mean-median & Min-max \\
\hline Age & 37.97 & $19-84$ & 39.00 & 18 & 38.48 & 18 \\
\hline & 39.00 & & 34.00 & 70 & 35.50 & 84 \\
\hline Length of suffering DM & $\begin{array}{l}5.26 \\
4.00\end{array}$ & $1-20$ & $\begin{array}{l}6.94 \\
5.00\end{array}$ & $\begin{array}{l}1 \\
20\end{array}$ & $\begin{array}{l}6.10 \\
4.00\end{array}$ & $\begin{array}{l}1 \\
20\end{array}$ \\
\hline
\end{tabular}

DM: Diabetes mellitus.

suffering from diabetes which is 6.1 years. The majority of respondents are female (77.4\%), more than some are highly educated $(56.5 \%)$ and does not work $(54.8 \%)$, and the majority of them do not have a Glycometer (66.1\%). The average score obtained a different mean value between the family's ability to detect hypoglycemic episodes of pre-test and post-test conditions, as shown in Table 3.

Table 3 shows that there is a different mean values in the family knowledge between experimental groups and control groups to detect hypoglycemic episodes before and after DSME mentoring.

Based on the table 4, known average difference value of experimental group (-6.55) and-control group $(-3.43)$. There was effectiveness of DSME on family knowledge to hypoglycemia episodes detection among T2DM ( $p=0.0001)$, including in the control group $(p=0.002)$

\section{Discussion}

DSME assistance affects the knowledge to detect hypoglycemic episodes in DM. Self-management can be achieved by education of diabetes selfmanagement [22]. Education improves the patient's knowledge on his or her illness and how the patient should be concerned, providing knowledge of how to change the lifestyle [23]. The family's knowledge to detect episodes of hypoglycemia rises from an average score of $9.45-12.26$. It is due to the approach in DSME using educational principles. Education is an effort for people to behave or adopt health behaviors by means of persuasion, solicitation, providing information, providing awareness, and others related to education or health counseling. The provision of health education is intended to raise awareness, give, or improve the public's knowledge of the maintenance and improvement of health for both yourself, family and society [24].

DSME is an ongoing process to develop awareness or knowledge, skills, and ability of DM patients to conduct self-care. This study was conducted the influence of human rights education (HRE) approach education obtained results that education with HRE approach can improve knowledge and attitude of dietary adherence in DM type two patients in Makassar Public Health Center after being given education for 3 weeks [25]. Family knowledge and support will strengthen the change in the attitude of sufferers. Families participate in the implementation of education with DSME principle approach by providing assistance, providing input, and reminding patients to adhere to treatment [26].

The results showed that there were differences found in the effectiveness between the experimental group and the control group related to the families' ability improvement to detect hypoglycemic episodes or family-based DSME assistance on the ability to

Table 2: Characteristics of respondents according to gender, education, occupation, and glucometer ownership of type 2 diabetes mellitus

\begin{tabular}{|c|c|c|c|c|c|c|}
\hline \multirow[t]{2}{*}{ Characteristics } & \multicolumn{2}{|c|}{ Intervention } & \multicolumn{2}{|c|}{ Control } & \multirow[t]{2}{*}{ Total } & \multirow[t]{2}{*}{$\%$} \\
\hline & $f$ & $\%$ & $f$ & $\%$ & & \\
\hline \multicolumn{7}{|l|}{ Gender } \\
\hline Male & 7 & 22.6 & 17 & 54.8 & 24 & 38.7 \\
\hline Female & 24 & 77.4 & 14 & 45.2 & 38 & 61.3 \\
\hline \multicolumn{7}{|l|}{ Education } \\
\hline None & 0 & 0 & 1 & 3.2 & 1 & 1.6 \\
\hline Elementary school & 3 & 9.7 & 3 & 9.7 & 6 & 9.7 \\
\hline Junior high school & 4 & 12.9 & 4 & 12.9 & 8 & 12.9 \\
\hline Senior high school & 21 & 67.7 & 14 & 45.2 & 35 & 56.5 \\
\hline College & 3 & 9.7 & 9 & 29.0 & 12 & 19.4 \\
\hline \multicolumn{7}{|l|}{ Occupation } \\
\hline Civil servant & 1 & 3.2 & 2 & 6.5 & 3 & 4.8 \\
\hline Labor & 0 & 0 & 2 & 6.5 & 2 & 3.2 \\
\hline Farmer & 0 & 0 & 1 & 3.2 & 1 & 1.6 \\
\hline $\begin{array}{l}\text { Civil servant } \\
\text { pensionary }\end{array}$ & 4 & 12.9 & 4 & 12.9 & 8 & 12.9 \\
\hline Entrepreneur & 4 & 12.9 & 1 & 3.2 & 5 & 8.1 \\
\hline Private employee & 1 & 3.2 & 8 & 25.8 & 9 & 14.5 \\
\hline Unemployed & 21 & 67.7 & 13 & 41.9 & 34 & 54.8 \\
\hline \multicolumn{7}{|l|}{ Glucometer ownership } \\
\hline Yes & 5 & 16.1 & 16 & 51.6 & 21 & 33.9 \\
\hline No & 26 & 83.9 & 15 & 48.4 & 41 & 66.1 \\
\hline
\end{tabular}


Table 3: Average family's knowledge score to detect hypoglycemic episodes before and after DSME mentoring of type 2 diabetes mellitus patients

\begin{tabular}{llll}
\hline Variable & Treatment & Mean & Min-max \\
\hline Family knowledge to hypoglycemic episodes detection (experiment) & Pre-test & $6-14$ & 10.71 \\
& Post-test & 12.39 & 2.09 \\
Family knowledge to hypoglycemic episodes detection (control) & Pre-test & 9.45 & 1.80 \\
& Post-test & 12.26 & 1.48 \\
\hline
\end{tabular}

SD: Standard deviation

detect hypoglycemic episodes. This effectiveness emphasizes discussion and sharing complemented by a process of strengthening, motivation, and selfawareness given to the respondents and their families. The DSME process conducted during two classic meetings and follow-up through home visits has fostered motivation and awareness of respondents and families about the importance of the management of DM, especially the ability to detect hypoglycemic episodes in the anticipation of DM complications. Therefore, families and patients with DM need to identify the risk of hypoglycemia that may occur in DM patients. Based on the observations and interviews, the DSME assistance has not been conducted on DM patients in the area of Putri Ayu Public Health Center. Patients based on the results of the study are known to rarely come to geriatrics centers due to their preference on public health centers for control purposes and take medication per month. DSME activities require cooperation among families, health workers, and public health centers. Health worker can also act as family companions. Families who get assistance are expected to achieve independence in conducting DM patient care at home.

Family involvement in the DM patient selfmanagement process will provide optimal support to achieve treatment goals. Patients with good levels of family support exhibit good self-management behavior [27]. The family, in this case, can provide practical assistance, such as helping to perform blood glucose tests or identifying signs of hypoglycemic. Families can also act as a source of psychological strength by encouraging diabetics patients to be more healthy and controlled [28]. The character of a healthy family including good communication, supportive behaviors such as giving trust, entertaining and playing, sharing responsibilities, and being willing to help other family members in solving the problem. Family members can support the patient's self-management activities by raising patient awareness and assisting them in determining the purpose of treatment as

Table 4: Effectiveness of family knowledge to detect hypoglycemic episodes before and after family-based DSME

\begin{tabular}{|c|c|c|c|c|}
\hline Variable & Treatment & $t$ & Df & Sig. (two tailed) \\
\hline $\begin{array}{l}\text { Family knowledge to } \\
\text { hypoglycemic episodes } \\
\text { detection (experiment) }\end{array}$ & Pre-post & -6.55 & 31 & 0.0001 \\
\hline $\begin{array}{l}\text { Family knowledge to } \\
\text { hypoglycemic episodes } \\
\text { detection (control) }\end{array}$ & Pre-post & -3.43 & 31 & 0.002 \\
\hline
\end{tabular}

well as the plan that should be taken. Diabetes selfmanagement education can be used as an alternative method to improve the self-care of patients with DM at home. Thus, nurses as health workers in providing nursing care should carry out health promotion to the families and patients of DM regarding DM disease and early detection of episodes of hypoglycemia. Nurses are also expected to give efforts to facilitate changes in behavior and lifestyle.

\section{Conclusions}

This study found a significant improvement in the intervention by providing knowledge on the detection of hypoglycemic episodes to participants through the DSME program. Therefore, DSME may be clinically important to be further developed in Indonesia.

\section{References}

1. Shaw JE, Sicree RA, Zimmet PZ. Global estimates of the prevalence of diabetes for 2010 and 2030. Diabetes Res Clin Pract. 2010;87(1):4-14. https://doi.org/10.1016/j. diabres.2009.10.007 PMid:19896746

2. Kementrian Kesehatan RI. Suara Dunia Perangi Diabetes. Jakarta Kementrian Kesehatan RI; 2018. Available from: http://www. depkes.go.id/article/vi1ew/18121200001/prevent-prevent-andprevent-the-voice-of-the-world-fight-diabetes.html. [Last accessed on 2021 Aug 05].

3. Decroli E. In: Efendi Y, editor. Diabetes Mellitus Tipe 2. I. Kam, Alaxander. Center for Publishing Internal Medicine Faculty of Medicine Andalas University. Padang: 2019

4. Kementrian Kesehatan RI. Laporan Nasional Hasil Riskesdas 2013. Jakarta: Badan Penelitian dan Pengembangan Kesehatan; 2013.

5. Kementerian Kesehatan RI. Laporan Nasional Riskesdas 2018 Jakarta: Badan Penelitian dan Pengembangan Kesehatan; 2019. https://doi.org/10.14203/press.298

6. ADA. Standards of medical care in diabetes-2017. J Clin App Res Educ. 2017;40:S48-56.

7. Soelistijo SA, Novida H, Rudijanto A, Soewondo P, Suastika K, Manaf A, et al. Konsensus Pengelolaan Dan Pencegahan Diabetes Melitus Tipe 2 di Indonesia 2015. Buku Konsensus DM Tipe-2. $1^{\text {st }}$ ed. Jakarta: PB Perkeni; 2015. p. 11-4.

8. Setyohadi B. Kegawatdaruratan Penyakit Dalam. Jakarta: Pusat Penerbitan IImu Penyakit Dalam; 2011. https://doi. 
org/10.32763/juke.v12i2.164

9. Sudoyo AW, Alwi SB, Marcellus SS. Buku Ajar IImu Penyakit Dalam. $1^{\text {st }}$ ed. Jakarta: EGC; 2007.

10. Hudak CM, Gallo B. Keperawatan Kritis Pendekatan Holistik. $8^{\text {th }}$ ed. Jakarta: EGC; 2012.

11. Sutawardana JH. Phenomenology study the experience of persons with diabetes mellitus. Nurseline J. 2016;1(1):159-75.

12. Eid YM, Sahmoud SI, Abdelsalam MM, Eichorst B. Empowermentbased diabetes self-management education to maintain glycemic targets during ramadan fasting in people with diabetes who are on conventional insulin: A feasibility study. Diabetes Spectr. 2017;30(1):36-42. https://doi.org/10.2337/ds15-0058 PMid:28270713

13. Triyanto E, Isworo A, Rahayu E. Integrated Development Model to Improve Compliance in Patients with Diabetes Mellitus. Media Kesehat Masy Indones. 2015;11(4):228-34.

14. Nuari NA. Development of Self Empowerment Model and Quality of Life Improvement for Patients with Diabetes Mellitus Type 2. Ners LENTERA. 2016;4(2):152-65.

15. Nisa $K$, Hasneli $Y$, Woferst R. The Effectiveness of The Health Belief Model on Knowledge of DM-DISC diet management. Ners Indones. 2017;8(1):1-11.

16. Sudirman AA. Diabetes Mellitus, Diabetes self management education (DSME), and self care diabetik. In: Proceeding Gorontalo International Nursing Conference 2017; 2017. p. 1-11. https://doi.org/10.31227/osf.io/8kgpr

17. Nasab MN, Ghavam A, Yazdanpanah A, Jahangir $F$, Shokrpour N. Effects of self-management education through telephone follow-up in diabetic patients. Health Care Manag (Frederick). 2017;36(3):273-81. https://doi.org/10.1097/ hcm.0000000000000172 PMid:28738397

18. Funnell MM, Brown TL, Childs BP, Haas LB, Hosey GM, Jensen $B$, et al. National standards for diabetes self-management education. Diabetes Care J. 2011;34 Suppl 1:S89-96. https:// doi.org/10.2337/dc11-s089 PMid:21193633

19. Ridwan A, Barri P, Nizami NH. Effect of Diabetes Self Management Education through SMS on Knowledge of Diabetic Patients: A Pilot Study Arfiza. Idea Nurs J. 2018;9(1):65-71.
20. Rahayu E, Kamaluddin R, Sumarwati M. Pengaruh program diabetes self management education berbasis keluarga terhadap kualitas hidup penderita diabetes melitus Tipe II Di wilayah puskesmas II baturraden. J Keperawatan Soedirman (Soedirman J Nurs).2014;9(3):163-72. Available from: http://www.jks.fikes.unsoed.ac.id/index.php/jks/article/ view/185/86gmbran https://doi.org/10.32382/jmk.v11i1.521. [Last accesed on 2021 Aug 05].

21. Jambi HREC the HP of Keterangan Layak Etik Proposal Dengan Judul: Efektifitas Pendampingan Diabetes Self Management Education berbasis Keluarga Terhadap Kemampuan Mendete ksi Episode Hipoglikemia pada pasien Diabetes Mellitus, Jambi; 2019.

22. Adwan MA, Najjar YW. The relationship between demographic variables and diabetes self-management in diabetic patients in Amman city/Jordan. Glob J Health Sci. 2013;5(2):213-20. https://doi.org/10.5539/gjhs.v5n2p213 PMid:23445711

23. Eissn I. Factors influencing self-management of diabetes mellitus; a review article. J Diabetol. 2014;3(1):3-7.

24. Notoatmodjo S. Promosi Kesehatan Teori dan Aplikasi. Jakarta: PT Rineka Cipta; 2010.

25. Makassar PK, Self D, Education M, Signed W, Test R, Self D, et al. Pengaruh Edukasi Dengan Pendekatan Prinsip Diabetes Self Management Education (DSME) Dalam Meningkatkan Pengetahuan Diet Terhadap Kepatuhan Diet Pada Penderita Diabetes Mellitus Tipe 2; 2014. p. 511-6. https://doi. org/10.20473/cmsnj.v1i1.11927

26. Laili NR, Dewi YS, Widyawati IY. Education with The Principle Approach of Diabetes Self Management Education (DSME) Improves Dietary Adherence Behavior in People with Type 2 Diabetes Mellitus. Crit Med Surg Nurs J. 2012;1(1):1-9.

27. Kep S, Kritpracha C, Thaniwattananon P, Keperawatan I, Keperawatan $\mathrm{F}$, et al. Pengembangan Program Dukungan Manajemen Diri Diet Berbasis Keluarga Terhadap Perilaku Diet Pada Penderita Diabetes Mellitus Tipe 2 di Indonesia: A Literature Review; 2012. p. 357-70.

28. Paddison CA. Family support and conflict among adults with Type 2 diabetes: Development and testing of a new measure. Eur Diabetes Nursing. 2010;7(1):29-33. https://doi.org/10.1002/edn.152 